\title{
Recreation of history using augmented reality
}

\author{
Nilam Desai" \\ Assistant Professor, Smt. Chandaben Mohanbhai Patel Institute of Computer Applications, Gujarat, India
}

\section{(C2018 ACCENTS}

\begin{abstract}
History plays eminent role in culture representation of any place as heritage sites and monuments reflects tradition, art and culture of previous golden era. Since last few years, historical places get affected day by day due to pollutions, lack of maintenance and excessive tourism. It is necessary to preserve and interpret those valuable flashes of past time by usage of technologies. Museum is there that preserve history but it does not provide insight view in interactive manner and also it only reflects past of specific area. So there is a need to develop such platform that provide in depth visualization of that eminent past evolution. This can be achieved through rapid advance technologies in recent years such as virtual reality, augmented reality $(A R)$, mobile computing that enable transmission of historic architecture into multi dimension modelling in real environment. In recent year, various vital research and techniques have been introduced that allows virtual reconstruction of heritage sites that enhance lookout of these sites through handheld devices. This paper describes about usage of $A R$ in historical recreation as well as it elaborates previous work that has been done in this area and gives knowledge about technologies that allows creating application for AR oriented historical site.
\end{abstract}

\section{Keywords}

Augmented reality, heritage reconstruction, Virtual reality, Multi dimension modelling, Virtual history.

\section{Introduction}

Every region has vast diversity in history. Every place describes its culture through traditions, monuments, buildings, art and many other ways. With running time, changes occur and all past objects become history. History represent previous golden era, requires maintaining for upcoming generation. It is required for People of next generation to get aware about historical events. Now a day due to urbanization, pollution and any other things harm heritage sites. To maintain this valuable resources. To describe history, museum is there but it only displays few historical aspect of country, not includes all heritage sites of world. This can be lead towards forgotten of those places or may not reach to all people of world. Fast technology advancements enable to develop interactive applications. Technology traverses from text to media and now a day's multi-dimensional media.

\subsection{Two dimension images}

Two dimension images are computer generated digital graphics. This can be used give direct view of any object using colorful or black and white print.

*Author for correspondence
1.2Three dimension objects

Three Dimensional Images gives in depth view of any object, where object is interactive. It provides virtual appearance with multi perspective lookout. There are so many projects and applications available that convert 2D images to 3D images [1]. Using 3D visualization, it helps to maintain spatial information of cultural heritage sites. [2]3D view shows beautiful engraving and carving of monuments and building in effective way using digital devices. It allows creating interactive digital library of heritage sites that can be useful for next generations. It plays vital role in aiding people to interact with the past, learn from it and save our cultural assets digitally [3] (Figure 1).

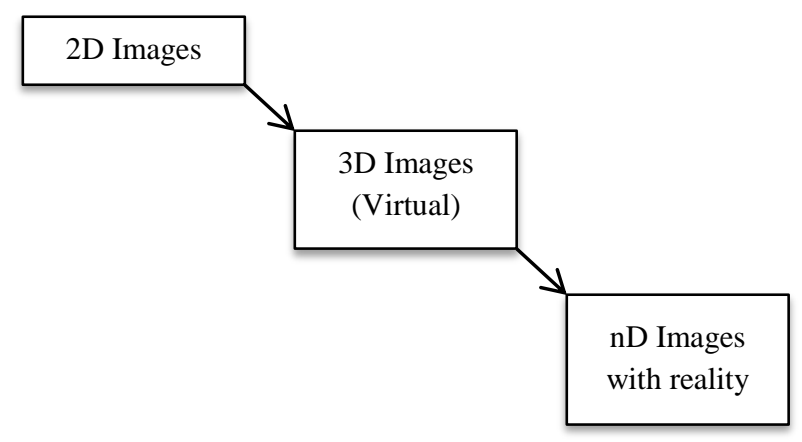

Figure 1 Image display technologies flow 


\subsection{Augmented reality}

It is a concept that shows virtual objects in real environment [4]. It creates multi-dimensional media and embeds it in real time world. Augmented reality can be used in many areas such as travel, education, medicine, archology, astrology where real time view is displayed with super imposed data in any format. It facilitates easiness in demonstration of any object as it creates illusion of it with live world that is more understandable.

Latest technologies associated to cultural and archaeological historical sites have given rise to new concepts such as Virtual History, Virtual archaeology, Virtual Museums, AR Heritage and many more. By creating virtual high dimension interactive heritage, it will have benefited to recreate damaged heritage site virtually. Through AR enable software and hardware, one can develop such application.

\section{Augmented reality and recreation of historical objects}

Augmented reality perceptions can be applied to rebuilding of historical object to have realist view of time (Figure 2). It enables the illustration and elucidation of reality for current and previous era.

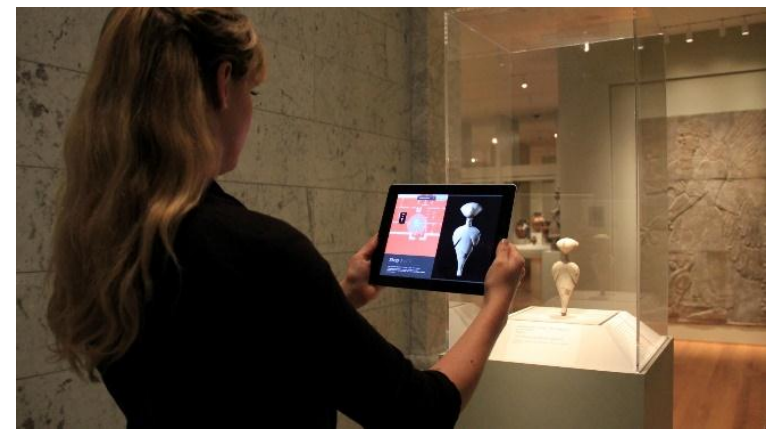

Figure 2 AR view of historical object [5]

In context of smart digital era, AR museum has been developed that gives in depth view of history element (Figure 3). It allows user to understand historical objects using multi-dimensional view.

Augmented reality combined with virtual reality devices and hand held devices such as mobile and tablets can provide great experience to people for look out at historical objects.

Augmented reality carries holograms of various elements to life. There are lots of technologies, application and web sites available that enables usage of AR.

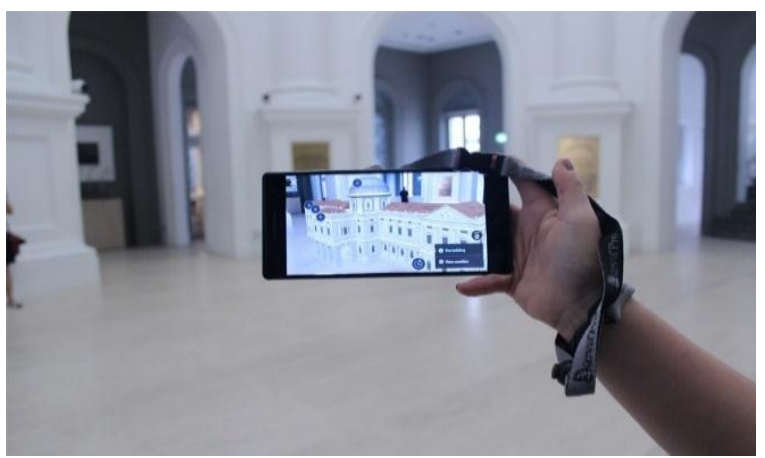

Figure 3 Analysis of museum through AR [6]

\section{Related work}

Much research has been dome to implement AR in reconstruction of history. In some countries, they have provided facility to view heritage sites in depth using AR embedded environment in museum (Figure 4).

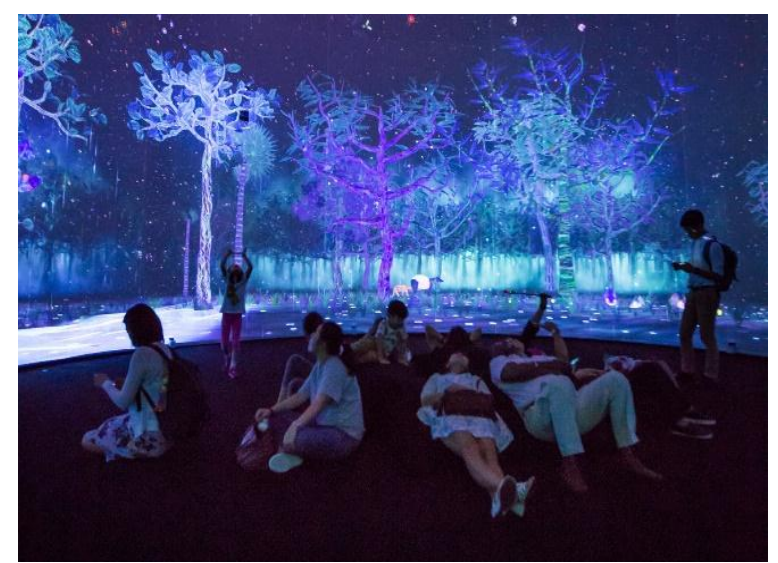

Figure 4 AR App: story of forest provide virtual view in real environment at National Museum of Singapore [7]

\subsection{AR Work for virtual historical site view}

Table 1 shows the AR application for history. It is shown in Figure 5.

Table 1 AR applications for history

\begin{tabular}{llll}
\hline $\begin{array}{l}\text { Ref. } \\
\text { No }\end{array}$ & Features & $\begin{array}{l}\text { App and Place } \\
\text { where used }\end{array}$ \\
\hline$[8]$ & $\begin{array}{l}\text { Efficient AR visualisation } \\
\text { scenarios for complementing } \\
\text { broken or damaged real } \\
\text { objects. }\end{array}$ & Philippine history \\
\end{tabular}




\begin{tabular}{|c|c|c|}
\hline $\begin{array}{l}\text { Ref. } \\
\text { No }\end{array}$ & Features & $\begin{array}{l}\text { App and Place } \\
\text { where used }\end{array}$ \\
\hline [9] & $\begin{array}{l}\text { Enable holographic view of } \\
\text { astronaut Gene Cernan } \\
\text { hovers over the real Gemini } \\
9 \text { space capsule. }\end{array}$ & $\begin{array}{lr}\text { Heroes } & \text { and } \\
\text { Legends, } & \text { Kennedy } \\
\text { Space } & \text { Center, } \\
\text { Florida } & \end{array}$ \\
\hline$[10]$ & $\begin{array}{l}\text { Shows 3-D models of the } \\
\text { original sculptures and } \\
\text { historical information on the } \\
\text { original buildings. AR } \\
\text { allows the user to access } \\
\text { layers of information. }\end{array}$ & Plaster ReCast app \\
\hline [11] & $\begin{array}{l}\text { It allows to see how a } \\
\text { vintage radio falls apart into } \\
\text { pieces as well as can look } \\
\text { and move around in a virtual } \\
\text { 3D television. Pictures on } \\
\text { the wall become alive, life } \\
\text { size 3D animated objects } \\
\text { appear when the visitor } \\
\text { points his device onto the } \\
\text { marker. }\end{array}$ & ARworks \\
\hline [12] & $\begin{array}{l}\text { It includes Site investigation, } \\
\text { the history of the site, from a } \\
\text { first Australian perspective, } \\
\text { to European arrival and the } \\
\text { impact of colonial settlement } \\
\text { with video and audio } \\
\text { embedded with AR. }\end{array}$ & MCA AR \\
\hline [13] & $\begin{array}{l}\text { It gives real footage and 3D } \\
\text { models of heritage content at } \\
\text { Science Center, Montreal, } \\
\text { Canada, using mobile. }\end{array}$ & $\begin{array}{l}\text { Demo: Towards } \\
\text { Historical } \\
\text { Sightseeing }\end{array}$ \\
\hline [14] & $\begin{array}{l}\text { It displays Cultural Heritage } \\
\text { Layer which show original } \\
\text { 2D content superimposed on } \\
\text { real environment, it is robust } \\
\text { marker less tracking } \\
\text { application. }\end{array}$ & $\begin{array}{l}\text { Cultural heritage } \\
\text { applications }\end{array}$ \\
\hline
\end{tabular}

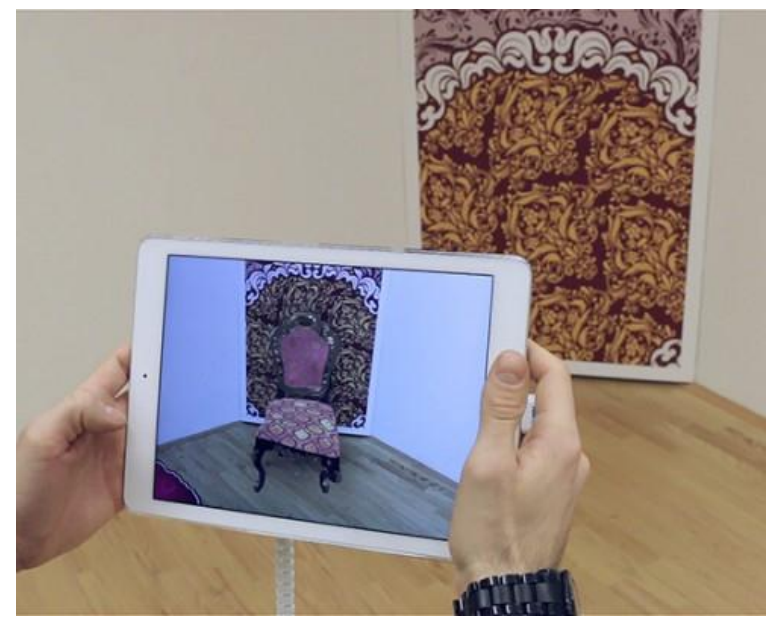

Figure 5 ArWork App to view heritage chair in 3D [11]

\subsection{Related project work}

For educational purpose Igpaw: Intramuros app has been developed that describes the design of an AR game for Philippine history [15]. A project has been initiated by project at the New Philadelphia National Historic Landmark, located in Pike County which offers opportunities for historical interpretation using augmented reality [16]. European project has been started to recreate history using AR and other media named 'CHESS: Cultural Heritage Experiences through Socio-personal interactions \& Storytelling'. They have created consist of stages such as scripting, layering, producing and editing to provide $\mathrm{AR}$ atmosphere [17]. AR is also used to preserve space related historical elements. Seattle's Museum of Flight has been created augmented-reality based application that shows a full-scale holographic model of the interior of the first 737 jet, that was first used as a Boeing flight test aircraft in 1974 [18]. MixAR is a system to give visualization of virtual buildings augmented upon real surroundings while letting soft switches amongst its interiors and outsides using mobile device [19].A computational model of AR has been introduced to simulate and visualize Egyptian cultural heritages which are The Pyramids and Giza plateau [20]. One small work has been done to explore the cultural heritage of Indonesia through 3D model [21].

\section{Display technologies for AR application}

There are many devices available up to now to visualize data in multi-dimensional form through AR applications. These devices range from a tiny spectacle to hand held gadgets that allows interacting with object incorporating real life environment. There are two categories are available: Marker Based and Image Based. Some display technologies are elaborated below.

\subsection{Head mounted device: HMD}

HMD is a display device placed on the head or as part of a helmet and that shows both images of the real and virtual environment over the user's vision of the world. HMD can either be video-see-through or visual see-through [22].

\subsection{Hand held devices}

Handheld devices are small computing devices with a display that the user can hold in their hands It uses video-see-through systems to overlay visuals onto the live environment and use sensors, such as digital compasses and GPS units for tracking sensors, fiducially marker systems and many more [22]. 


\section{Future work}

To preserve history, Augmented Reality concepts can be used that provide way to reconstruct damaged or lost part of heritage sites. This kind of work is beneficial education, research and many more. Three are some challenges to work with AR such as security, managing high resolution data in small devices [23]. It will be more effective if it can have combined with Big data, IoT and cloud computing as it provides more data availability and efficiency.

\section{Conclusion}

History is reflection of any place so that it is necessary to maintain it in proper way. Through Image Processing technologies such as Augmented Reality and now days mixed reality embedded with various hand held devise, history will be reconstructed as well as preserve for many years. There are many projects which are working on it. This can be useful to researcher as well as in education. There are lot of tools and technologies available in market that allows developing such kind of applications. Also new concepts can be created to maintain precious historical object by associating IoT and other emerging technologies with augmented reality.

\section{Acknowledgment}

I am thankful to Dr. Atul Patel, Dean and Principle, CMPICA, CHARUSAT and Dr. Chirag Patel, Assistant Professor, CMPICA, CHARUSAT for their valuable guidance and my parents for all things which I have.

\section{Conflicts of interest}

The authors have no conflicts of interest to declare.

\section{References}

[1] Konrad J, Wang M, Ishwar P, Wu C, Mukherjee D. Learning-based, automatic 2D-to-3D image and video conversion. IEEE Transactions on Image Processing. 2013; 22(9):3485-96.

[2] Bentkowska-Kafel A, MacDonald A. Digital techniques for documenting and preserving cultural heritage. ARC press; 2018.

[3] Ioannides $M$, Davies $R$, Chatzigrigoriou $P$, Papageorgiou E, Leventis G, Nikolakopoulou V, et al. 3D Digital libraries and their contribution in the documentation of the past. In mixed reality and gamification for cultural heritage 2017 (pp. 161-99). Springer, Cham.

[4] Azuma R, Baillot Y, Behringer R, Feiner S, Julier S, MacIntyre B. Recent advances in augmented reality. IEEE Computer Graphics and Applications. 2001; 21(6):34-47.

[5] Augmented reality window at the new museum. http://www.augmentedrealitytrends.com/augmentedreality/new-museum.html. Accessed 18 January 2018.

[6] Lim YX. Augmented reality gets real at national museum.

https://www.theurbanwire.com/2017/04/augmentedreality-gets-real-at-national-museum/ Accessed 17 January 2018.

[7] Ho V. Singapore museum adds an interactive virtual forest. https://mashable.com/2016/12/09/virtual-forestsingapore-national-museumteamlab/\#Rlncsq92kOqW. Accessed 18 January 2018.

[8] Liarokapis F, White M. Augmented reality techniques for museum environments. Mediterranean Journal of Computers and Networks. 2005; 1(2):95-102.

[9] Heroes and Legends, Kennedy Space Center, Florida. https://www.kennedyspacecenter.com/exploreattractions/heroes-and-legends. [Accessed 18 January 2018].

[10] Henry M, Plaster ReCast at the Carnegie Museum of Art. http://aiapgh.org/feature-articles/plaster-recast-atthe-carnegie-museum-of-art-hall-of-architecture/ Accessed 18 January 2018.

[11] VR/AR and kinect experience in a historical museum. http://www.arworks.com/en/portfolio-item/vrar-andkinect-experience-in-a-historical-museum/. Accessed 18 January 2018.

[12] Keir, Augmented reality projects at the MCA. http://keirdotnet.net/content/augmented-realityprojects-at-the-mca/. Accessed 18 January 2018.

[13] Song M, Mokhov SA, Mudur SP, Bustros JC. Demo: towards historical sightseeing with an augmented reality interactive documentary app. In proceedings of the games entertainment media conference 2015. IEEE

[14] Zoellner M, Keil J, Drevensek T, Wuest H. Cultural heritage layers: integrating historic media in augmented reality. In international conference on virtual systems and multimedia 2009 (pp. 193-6). IEEE.

[15] Rodrigo MM, Caluya NR, Diy WD, Vidal EC. Igpaw: intramuros-design of an augmented reality game for Philippine history. In proceedings of the international conference on computers in education 2015.

[16] Amakawa J, Westin J. New Philadelphia: using augmented reality to interpret slavery and reconstruction era historical sites. International Journal of Heritage Studies. 2018:1-7.

[17] The CHESS project. http://www.chessexperience.eu/. Accessed 18 January 2018.

[18] Geronikolakis E. Virtual tour onto Nasa's historic 737 Jet with the help of augmented reality. https://www.vi$\mathrm{mm}$. eu/2018/01/24/virtual-tour-onto-nasas-historic737-jet-with-the-help-of-augmented-reality/. Accessed 18 January 2018.

[19] Narciso D, Pádua L, Adão T, Peres E, Magalhães L. Mixar mobile prototype: visualizing virtually reconstructed ancient structures in situ. Procedia Computer Science. 2015; 64:852-61. 
ACCENTS Transactions on Image Processing and Computer Vision, Vol 4(10)

[20] ACE B. Simulating Egyptian cultural heritage by augmented reality technologies. Sustainable vital technologies in engineering \& informatics 2016.

[21] Putra EY, Wahyudi AK, Dumingan C. A proposed combination of photogrammetry, augmented reality and virtual reality headset for heritage visualisation. In international conference on informatics and computing 2016 (pp. 43-8). IEEE.

[22] Carmigniani J, Furht B, Anisetti M, Ceravolo P, Damiani E, Ivkovic M. Augmented reality technologies, systems and applications. Multimedia Tools and Applications. 2011; 51(1):341-77.

[23] Azuma RT. The most important challenge facing augmented reality. Presence: Teleoperators and Virtual Environments. 2016; 25(3):234-8.

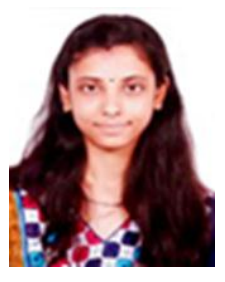

Nilam Desai from Nadiad. I am currently working as Assistant Professor at Smt. Chandaben Mohanbahi Patel Institute of Computer Applications(CMPICA), Charotar University of Science and Technology. I have degree of Master of Computer Application.

Email: nilamdesai.mca@charusat.ac.in 